\title{
The Implementation of E-Court in Administrative Court to Develop Access to Justice in Indonesia
}

\author{
Aju Putrijanti", Kadek Cahya Susila Wibawa \\ Diponegoro University, Semarang, Indonesia
}

Received: 19/08/2020

Accepted: 19/10/2020

Published: 20/03/2021

\begin{abstract}
Administrative Court has an absolute competence to settle administrative disputes. Sustainable Development Goals is a program conducted by United Nations with seventeen goals and the aims is no one left behind. The difficulty to get access to justice is one issue of SDG's. This is normative legal research and research data used are secondary data, and data will be analyzed using descriptive analysis. Research questions are how the role of administrative court in e-court is, and how access to justice from is administrative court perspectives. Development of technology gives benefits also in litigation process, and judiciary systems in Indonesia have implement the use of technology into regulations. Judiciary system developed the e-court with aims to increase the public service of judiciary system. Implementation of ecourt for Administrative Court cannot fully electronically, since there are two processes which cannot implement using the technologies. The absolute competence of Administrative Court become broaden, after Law Number 30 Year 2014 of Governance Administration stipulated, which gives access to justice become easier for people to protect their rights. The novelty is Administrative Court using hybrid system between the conventional and modern system, since dismissal process and preparatory examination should be done before enters the court room. The shifting paradigm of administrative law gives more access to justice for justice seeker, because it gives more competence to Administrative Court.
\end{abstract}

Keywords: Administrative Court, E-court, Access to Justice

\section{Introduction}

Indonesia is State Law based on Article Number 1 paragraph 3 of Constitution of 1945, this emphasized that government's action in public or private matter due to implementation, should be based on regulations. As state law, Indonesia has its own characteristic which can be seen from philosophy, nature of sovereignty, state organization, and human rights. The historical background shows there is shifting implementation of state law, it's become democracy state law not absolute state law, which require the role of public and human rights protection, and public as subject to make policy [1]. This make consequences that government has to guarantee to protection of human rights, while people can make lawsuit against government to Administrative Court (hereinafter is Court) [2]. The supervision to executive can be done by Court for external supervision besides internal supervision. Supreme Court is the highest level in judiciary system for general court, religious court, military court and administrative court, and Constitution Court with absolute competence regarding the constitutional review.

In June 1992 at Rio de Janeiro United Nations started on Earth Summit about plan action to build global partnership for sustainable development to improve human lives and protect the environment, and has transform and develop the Sustainable Development Goals, and put 17 goals to implement and achieve in 2030. The 17 goals are: no poverty, zero hunger, good health and wellbeing, quality education, gender quality, clean water and sanitation, affordable and clean energy, decent work and economic growth, industry innovation and infrastructure, reduced inequalities, sustainable cities and communities, responsible consumption and production, climate action, life below zero, life on land, access to justice and strong institutions, partnership for the goals. Quoted from SDG's Indonesia, that 17 goals are classified into 4 (four) pillars i.e. economy, social development, environment, law and good governance. Access to justice is a classic issue, also in Indonesia, this caused by some reasons, namely lack of education, economy, transportation and culture, then it's become a circle of unsolved problems, for period of times

Supreme Court as the highest Court for 4 (four) judicial bodies, had been tried to make a blue print of Supreme Court Reformation, and one of the aims is to make modern judiciary. Refer to this, and related with SDG's access to justice and strong institutions, the Supreme Court has developed e-court for judiciary system and this program has been stipulated in Supreme Court Regulation Number 1 Year 2019 of Case Administration and Court Electronically, besides they also develop and implement Case Information System in every judicial body. This is an innovation because public can easily know the process for cases, without any difficulties to get the newest information; it is transparency and modernization for government in order to

Corresponding author: Aju Putrijanti, Diponegoro University, Semarang, Indonesia. E-mail: Corresponding Author: ajupatrijanti.undip@yahoo.com 
implement the principle of good governance [3].

Court is a judiciary body under Supreme Court of Indonesia, which has absolute competence to investigate, decide settle the administrative dispute between individual and or legal entity against government, and demand to cancel the government's decree. Court was established by Law Number 5 Year 1986 of Administrative Court and had been twice amendments, followed the amendments of Constitution of 1945 regarding the judiciary system. Court has an important role in law enforcement of administrative law, protect the civil rights, and keep the balance condition between public and government while they have to implement the regulations to arrange the State.

Regarding the goals of SDG's and reformation of judiciary system, Court has implemented the e-court based on regulations. This study aims to investigate the implementation of e-court in administrative court to develop access to justice in Indonesia. More specifically, it puts emphasis on the absolute competence of Administrative Court after Law Number 30 Year 2014 of Governance Administration was stipulated. The purpose of his study is to explore the extent to which the access to justice become easier for people to protect their rights by highlighting the role of Administrative Court in using hybrid system between the conventional and modern system.

\section{Method}

This study is a qualitative study with the aim of analyzing and investigating the hybrid system between the conventional and modern system and the absolute competence of Administrative Court after Law Number 30 Year 2014 of Governance Administration. Qualitative research is research that intends to understand the phenomena experienced by research subjects such as behavior, perception, motivation, action, etc. in a holistic manner, and by means of description in the form of words and language, in a specific natural context and by making use of various natural methods [4]. This is a normative research, which use conceptual, statute and comparative approach. The normative method is in this study the normative method is used to analyze the Administrative Court after Law Number 30 Year 2014 of Governance Administration. The conceptual model is a representation of a system composed of a composition of concepts that are used to help know, understand, or simulate a particular subject. A conceptual approach is a type of approach in legal research that provides an analysis point of view of problem solving in legal research seen from the aspects of the legal concepts behind it, or can even be seen from the values contained in normalizing a regulation in relation to the concepts the concept used [5].

As for comparative research, it is a kind of descriptive research that seeks to find answers fundamentally about cause and effect, by analyzing the factors that cause the occurrence or appearance of a particular phenomenon [6]. In this study, conceptual methods were used to explore hybrid systems in the Administrative Court after Law Number 30 Year 2014 of Governance Administration, whereas the comparative method is used to assess conventional and modern systems in hybrid systems in the Administrative Court after Law Number 30 Year 2014 of Governance Administration. The primary data are related regulations in the Administrative Court after Law Number 30 Year 2014 of Governance Administration, and the secondary data are journals, research results related to the Administrative Court after Law Number 30 Year 2014 of Governance Administration.
The data will be analyzed in qualitative method with descriptive analysis.

\section{Results}

Refer to theory of system of law by L. Friedman, it is consisting of legal culture, legal substance and legal structure [7]. The use of IT for court process is brand new for public, it is relating with legal culture in system of law. There are 2 (two) concepts of court, first the real court it means with building and infrastructures, but paperless. Second is the virtual court, there is no court building, but judges, parties, lawyers and witnesses can have meeting and investigate, using the IT facility, including the digital signature and documents checking. In India it was first established in New Delhi, but in U.K. they are using hybrid type between paperless court and virtual court [8]. The readiness of society to accept, implement and use of IT is important to achieve the aims. E-litigation in Singapore Judicial Institutions, there are some issues arise, i.e. about the budget to improve the quality of e-litigation, lack of human resources, security and authentication, and modernization of judicial institutions in Indonesia will succeed based on simple, speedy and low-cost process [9].

Legal structure is about the institutions, court administration, infrastructures, and judges to improve their competence. Court should be openness, transparency, accountable as part of principles of good governance. Public wants to know easily and fast the process starting when they submit the lawsuit until the execution of judge verdict, including the cost. Legal substance refers to the regulations of e-court and Court, there should be compatibility between related regulations. If there is legal gap, it will become problems for public, whereas they are the subject to judiciary system.

Supreme Court has applied the modern information technology (IT) as implementation of Law Number 48 Year 2009 of Judiciary System, aims to improve efficiency and affectivity of dispute settlement by reduce the case arrears, but there is no decrease in number significant during the time 1986 until 2007, implementation of IT not been used maximized to improve the court's performance, because IT used only to register the cases [10]. Based on the above research, Supreme Court trying to improve and maximize the use of IT and application e-court for general court, religious court, military court and administrative court. Supreme Court Number 3 Year 2018 of Electronic Case Administration was the first regulation about use of IT but only for case administration. Improvement has made in Supreme Court Regulation Number 1 Year 2019 of Case Administration and Court Electronically which added the court electronically and some important points related.

In the explanation of Supreme Court Regulation Number 1 Year 2019 of Case Administration and Court Electronically, stated that this is based on Article Number 2 of Law Number 48 Year 2009 of Judiciary System and to renew the previous Supreme Court Regulation Number 3 Year 2018 of Court Administration. This Supreme Court Regulation Number 1 Year 2019 of Case Administration and Court Electronically, aims to simplify the process of lawsuit, reduce cost of proceed, become easy to access to justice.

In Supreme Court Regulation Number 1 Year 2019 of Case Administration and Court Electronically implement in general court (private law), religious court, administrative court and military court. E-court process starts from e-filling, where the register user and other user while they should fulfill the 
requirements for each user. The next process is e-payment to pay the advance money, e-summons is information to all parties, and the last is e-litigation is the online litigation.

Article 15 of Supreme Court Regulation Number 1 Year 2019 of Case Administration and Court Electronically stated that information to all parties given electronically based on their agreement and defendant's approval not required for Court and emphasized in Article 20. Before the electronically court begin, judge should give information to parties about their rights and duties during the court. The judge will give court calendar to parties through Court Information System, all the supported documents must be given to judge at exact time as scheduled, then judge will give those documents to other parties, when parties does not give the documents without any legal reason, it is considered that they do not use their rights properly. The third party may join the court by make plea of intervention letter and commit to follow the court electronically, but when they refuse, then judge will not accept the plea.

Evidentiary process follows procedural law for each court, it is clearly understood that there is different procedural law also for rules of evidence. If parties agree for evidentiary process using the teleconference or any kind of audio-visual communication types that makes possible for everyone to see and follow the process. The use of written documents starts in Article 22, included letter of evidence electronically. In the regular court process, the evidentiary process is important, because judges and parties will check the originality of documents, asking questions to witnesses. If parties do not agree to have evidentiary process using audio visual communication or teleconference, then it can be done using regular or conventional process, the judges, parties and witnesses will come physically to the court room. It shows that Supreme Court follows the development of information technology and adopt into the court electronically, certainly follows with regulations that is allow using regular or conventional process, in order to give access to justice more easily to whomsoever needs.

Based on Law Number 5 Year 1986 of Administrative Court, there are 2 (two) process as particular process in Court before enter the court room, i.e. Dismissal Process (vide Article 62) and Preparatory Examination (vide Article 63). In Supreme Court Regulation Number 1 Year 2019 of Case Administration and Court Electronically there is no regulations for the particular process and it is not possible to erase those process. However, the principle lex specialis derogat legi generali is implementing due to this regulations, Act Number 5 Year 1986 of Administrative Court override the Supreme Court Regulation Number 1 Year 2019 of Case Administration and Court Electronically, for judiciary purpose. The dismissal process and preparatory examination implement using the conventional process and based on regulations of Administrative Court, after complete, the process will go to e-litigation as regulated in Supreme Court Regulation Number 1 Year 2019 of Case Administration and Court Electronically. In the Court, there is a hybrid process due to particular process which cannot override. Sudarsono, in other hand, said that dismissal process and preparatory examination, evidentiary process and verdict still use conventional process, whereas his research based on Supreme Court Number 3 Year 2018 of Electronic Case Administration [11]. There are no regulations about dismissal process, preparatory examination and evidentiary process in the Supreme Court Regulation Number 1 Year 2019 of Case Administration and Court Electronically, it means that the process refers to Law Number 5 Year 1986 of Administrative Court and its amendments.

\section{Discussion}

Access to justice is rights to everyone have their voice to be heard, rights to vote, rights to be treated non-discrimination against race, religion, nation, equal rights. There are many opinions about the meaning of access to justice, depends on the point of view, but still some common understanding about access to justice. UN has program to help, assist the country which has difficulties to eliminate, decrease the factors caused obstruction to access to justice. Access to justice is about good life, it's about accessing equality, education, food, security, good laws, courtroom, judges, etc. it's about ultimately the point, besides understanding, education, prevention to accessible and effective justice [12]. The problems related to courtroom and infrastructure looks is the primary obstacle, the legal system should be well informed to parties and lawyers.

Discrimination and inequality of gender, is annoying and injuring the human rights, disability for those with low income to get the legal aid also barrier to access to justice [13]. It is also challenge to provide regulations for gender, disability and low income to get their rights properly. Principle of no discrimination should be upholding, for disability, government should prepare a specific tool to make lawsuit or any kind relates with judicial process, so does for gender, there should be a friendly regulation. Lawyers needs to conceptualizing access to justice, to explore and to expand visions of the role's lawyers, cooperation with other disciplines to achieve equal access to justice [14]. In the U.S. they have used the modern information technology to increase the legal-aid services. Access to justice and legal information has grown highly, especially for low-income person. Statewide broaden their legal-aid, where providers cooperate with legal advisors' organization to give assistance of their legal problems. Even though government has made collaboration with providers, legal professional organizations, there is still difficult to reach the low-income people. Technology also helps disabilities to fulfill their rights, meaning access to courtroom and legal-aid [15].

The report made by Organization for Economic Cooperation and Development [16] gives information about new technology may revolutionize legal services for next decades, some countries put judicial services via online. Within the new technology, people can improve access to justice as easy as it is, for some countries had already used for legal purposes. Good governance also can be seen from how people get access to justice, it's about the judge verdict, judiciary process, efficient, unbaits, consistent and transparency about the cost and time to proceed for litigate, and the court is an adaptive system to resolve conflict, problems and gives a fair outcome [17].

The implementation of e-court shows benefit i.e. to realize the principle of simple, fast and low cost, to create an accountable, transparent, effective, efficient, professional, transparent law behavior, and impact to justice seeker since it become easy to access and control the progress of litigation [18]. In his research, showed the public satisfaction survey conducted by LP3ES with Supreme Court Supervisory Agency, that current public satisfaction increased by $6.7 \%$ in the period between 2014-2018. Modern judiciary has to implement of IT to reduce the obstacle to get access to justice.

To improve access to justice, Canada using 2 (two) approaches, first is institutional approach and based on 3 (three) 
principles, i.e.: rule making, legal normativity and expertise who involved in the institutional. Rule-making refer to the regulations made by government, legal normativity may describe by social behavior prescribed by law to regulate relationship between public, individual and legal entity, expertise means the ability for those involve in the judiciary process. Institutional approach is still relevant di Canada, but it also has limitations. Second is the contextual approach, based on 3 (three) principles, i.e.: social regulation, inter-normativity and proactivity of actors. Social regulations refer to method that govern relationship between persons, inter-normativity is refer to social behavior prescribed a punishable in certain condition, proactivity is relates to autonomy of parties to a dispute in selecting norms to prevent and accomplished the disputes [19].

The enactment of Law Number 30 Year 2014 of Government Administration brings new paradigm in administration law in Indonesia, and also broaden the access to justice for public, by open "zero space" to justice seeker while previously they cannot get access to justice. There are 5 (five) points in Law Number 30 Year 2014 of Government Administration, i.e. administrative effort, positive fictitious, declarative decision, object of settlement and abuse of power, while all five points gives broaden competence to Court [20]. Previously, government tort filed lawsuit to general court and based on Code of Civil Law, this has historical background while Indonesia colonialized by Dutch. As regulated in Article 87 of Law Number 30 Year 2014 of Governance Administration, that definition of state administration decisions had been broaden not just as regulated in Law Number 5 Year 1986 of Administrative Court and its amendments, but also written decision which include factual action.

This important shifting paradigm in administrative law is to confirm that government tort goes to Court, but exclude the factual action which arise in military, it will go to military court [21]. About abuse of power also become absolute competence to Court, while this matter becomes debatable between corruption court as specialized court under general court and Court. Based on procedural it is clearly stated that investigation should be done by Court first, and after completed, the case goes to corruption court. It is important to make reformation of Court, especially about the absolute competence [22]. The limited absolute competence is the default to settle the administrative dispute, because it cannot reach the administrative dispute arises, and directly restricted access to justice, and harmonization between related regulations. It is important to harmonize the regulations because it is legal substance refer to Theory of Law, as important as legal culture and legal structure to get access to justice [23].

\section{Conclusion}

Implementation of E-Court in Court is hybrid system, because dismissal process and preparatory examination should be done before enter the court room, and refer to regulations of e-court, there is no specific regulation about this process. The shifting paradigm of administrative law after Law Number 30 Year 2014 of Governance Administration had been stipulated makes Court have more competence to gives justice. The variety of lawsuit and application against government, according to access to justice that government has to offer ways so public can easily get access to justice and brings justice to everyone, and show the strong political will to improve the public services. Harmonization between regulations is important, while people have to adjust to development of technology to get access to justice, and bureaucracy reformation also needed.

\section{Ethical issue}

Authors are aware of, and comply with, best practice in publication ethics specifically with regard to authorship (avoidance of guest authorship), dual submission, manipulation of figures, competing interests and compliance with policies on research ethics. Authors adhere to publication requirements that submitted work is original and has not been published elsewhere in any language.

\section{Competing interests}

The authors declare that there is no conflict of interest that would prejudice the impartiality of this scientific work.

\section{Authors' contribution}

All authors of this study have a complete contribution for data collection, data analyses and manuscript writing.

\section{References}

1. Subechi, I. (2012). Mewujudkan Negara Hukum Indonesia. Jurnal Hukum dan Peradilan, 1(3), 339-358.

2. Bimasakti, M. A. (2019). Lawsuit in administrative court after administrative proceedings based on perma no. 6 of 2018. Jurnal Hukum dan Peradilan, 8(3), 458-480.

3. Putra, D. (2020). A modern judicial system in Indonesia: legal breakthrough of e-court and e-legal proceeding. Jurnal Hukum dan Peradilan, 9(2), 275-297.

4. Moleong, L. J. (2005). Metodologi Kualitatif Edisi Revisi. Bandung: Remaja Rosdakarya.

5. Soekanto, S., \& Mamuji, S. (2007). Penelitian Hukum Normatif Suatu Tinjauan Singkat (Normative Legal Research, a Simple Review). Jakarta: Rajawali Pres.

6. Nazir, M. (2005). Metodelogi Penelitian. Jakarta: Ghalia Indonesia.

7. Friedman, L. M. (1969). Legal culture and social development. Law and society review, 29-44.

8. Prakash, S. B. (2014). E Judiciary: a Step towards Modernization in Indian Legal System. Journal of Education \& Social Policy, 1(1).

9. Kurniawan, M. B. (2020). Implementation Of Electronic Trial (ELitigation) On The Civil Cases In Indonesia Court As A Legal Renewal Of Civil Procedural Law. Jurnal Hukum dan Peradilan, 9(1), 43-70.

10. Nursobah, A. (2015). Pemanfaatan Teknologi Informasi Untuk Mendorong Percepatan Penyelesaian Perkara di Mahkamah Agung. Jurnal Hukum dan Peradilan, 4(2), 323-334.

11. Sudarsono, S. (2019). Konsep peradilan secara elektronik di lingkungan peradilan tata usaha negara. Tanjungpura law journal, 3(1), 42-64.

12. Farrow, T. C. (2013). What is access to justice. Osgoode Hall LJ, 51, 957.

13. Krishnan, J. K., Kavadi, S. N., Girach, A., \& Khupkar, D. (2014) Grappling at the Grassroots: Access to justice in India's Lower Tier. Harv. Hum. Rts. J., 27, 151.

14. Wallat, K. S. (2019). Reconceptualizing Access to Justice. Marq. L. Rev., 103, 581 .

15. Cabral, J. E., Chavan, A., Clarke, T. M., \& Greacen, J. (2012). Using technology to enhance access to justice. Harv. JL \& Tech., 26, 241.

16. OECD. 2016. "Leveraging the SDGs for Inclusice Growth : Delivering Access to Justice for ALL."

17. Tonn, B., Stiefel, D., Scheb II, J. M., Glennon, C., \& Sharma, H. K. (2012). Future of the courts: Fixed, flexible, and improvisational frameworks. Futures, 44(9), 802-811.

18. Santiadi, K. (2019). Expanding Access To Justice Through E-Court In Indonesia. Prophetic Law Review, 1(1), 75-89. 
19. Roberge, J. F. (2013). Emerging trends in access to justice and dispute resolution in Canada. URL: https://www. ramjam. ca/fileadmin/sites/droit/RAMJAM/Archives/Vol_4_no_2/Ram-

Jam_4_2_JeanFrancoisRoberge. pdf Accessed, 7, 18 .

20. Permana, T. C. I. (2015). Peradilan Tata Usaha Negara Pasca Undang-Undang Administrasi Pemerintahan Ditinjau Dari Segi Access To Justice. Jurnal Hukum dan Peradilan, 4(3), 419-442.

21. Bimasakti, M. A. (2018). Onrechtmatig Overheidsdaad Oleh Pemerintah Dari Sudut Pandang Undang-Undang Administrasi Pemerintahan/Act Against The Law By The Government From The View Point Of The Law Of Government Administration. Jurnal Hukum Peratun, 1(2), 265-286.

22. Manao, D. F. (2018). Penyelesaian Penyalahgunaan Wewenang Oleh Aparatur Pemerintah Dari Segi Hukum Administrasi Dihubungkan Dengan Tindak Pidana Korupsi. Jurnal Wawasan Yuridika, 2(1), 123.

23. Effendi, M. (2018). Peradilan Tata Usaha Negara Indonesia Suatu Pemikiran Ke Arah Perluasan Kompetensi Pasca Amandemen Kedua Undang-Undang Peradilan Tata Usaha Negara. Jurnal Hukum dan Peradilan, 3(1), 25-36. 